The

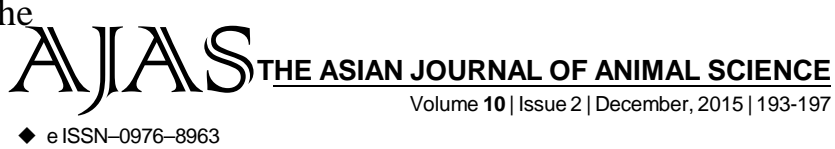

DOI : 10.15740/HAS/TAJAS/10.2/193-197 Visit us | www.researchjournal.co.in $\mathbf{S}$

RESEARCH ARTICLE.

\title{
Marketed surplus, consumption and disposal pattern of milk in Banswara district of Rajasthan
}

G.L. MEENA AND BHAVENDRA TIWARI

RII

Author for Corresponding -

\section{G.L. MEENA}

Department of Agriculture

Economics and Management, Rajasthan College of Agriculture,

Maharana Pratap University of

Agriculture and Technology,

UDAIPUR (RAJASTHAN) INDIA

Email: glm57@ rediffmail.com

See end of the article for

Coopted authors'
ABSTRACT...... The present study investigated marketed surplus, consumption and disposal pattern of milk in Banswara district of Rajasthan. The study covered 90 milk producers selected randomly from six villages which were post-stratified into small, medium and large herd size category. The study revealed that production, marketable surplus and marketed surplus of milk per household were 7.16 lit., 5.56 lit. and 2.81 lit., respectively. Marketed surplus of milk $(39.01 \%)$ was lower than marketable surplus of milk $(77.65 \%)$. Out of total milk retained at home (4.35 lit.), about 1.78 and 2.57 lit. milk were consumed as liquid and converted into milk products, respectively. The per capita per day availability and consumption of milk were found 245.23 and $149.07 \mathrm{~g}$, respectively. About 76.15 per cent marketed surplus of milk was sold by milk producers to un-organized sector and rest of surplus milk (23.85\%) to organized sector. The percentage of surplus milk sold through directly to consumers was the highest $(31.51 \%)$ followed by milk vendors $(30.18 \%)$, dairy co-operative societies $(23.85 \%)$ and tea shops $(11.26 \%)$ in the study area.

KEY WORDS...... Marketed surplus, Consumption, Disposal pattern, Milk

HOW TO CITE THIS ARTICLE - Meena, G.L. and Tiwari, Bhavendra (2015).Marketed surplus, consumption and disposal pattern of milk in Banswara district of Rajasthan. Asian J. Animal Sci., 10(2): 193-197.

ARTICLE CHRONICLE - Received : 27.10.2015; Revised : 18.11.2015; Accepted : 24.11.2015 